UDC 621.314

\title{
The Process Analysis in Domain of Two Variables
}

\author{
I. Ye. Korotyeyev, Prof., Dr.Sc., ORCID 0000-0002-7990-5413 \\ e-mail i.korotyeyev@iee.uz.zgora.pl \\ Institute of Electrical Engineering www.iee.uz.zgora.pl \\ University of Zielona Góra uz.zgora.pl \\ Zielona Góra, Poland
}

\author{
M. Klytta, Dr.Sc. ORCID 0000-0002-6832-0145 \\ e-mail Marius.Klytta@ei.thm \\ Department of Electrotechnics and Information Technology \\ University of Applied Sciences Mittelhessen \\ Giessen, Germany
}

\begin{abstract}
A steady-state processes in RLC circuit with power sources having incommensurable frequencies is considered. In such a circuit a periodic steady-state process does not exist. In order to obtain the periodic steady-state behavior an expansion of an ordinary differential equation is considered. This expansion is based on introducing of an additional time variable and therefore on transition from ordinary differential equations to partial differential equations with two time variables. Obtained differential equations are solved by use of the two-dimensional Laplace transform. Using double integrals expressions for a transfer function, active power and frequency responses for domain of two time variables are defined. Voltage and current amplitude-frequency characteristics of RLC circuit in the domain of two variables are presented.
\end{abstract}

Ref. 6, fig. 5.

Keywords — domain of two variables; frequency responses; two-dimensional Laplace transform.

\section{INTRODUCTION}

Processes in inverter circuits are dependent on control signals acting on power transistors. These signals result of frequencies that ratios are mostly irrational [1], [2]. In that case a steady-state behavior exists, but is not periodic. In order to obtain the periodic steady-state behavior it is expedient to expand an ordinary differential equation with one time variable to a partial differential equation with two independent time variables [3]. Such an approach allows to expand the well-known methods used for analysis of ordinary circuits with ordinary signals on circuits with irrational frequencies in acting signals.

The aim of this article is an expansion of such important circuit characteristics as a transfer function, frequency response and power in the domain of two time variables.

\section{MATHEMATICAL MODEL}

Let us consider an RLC circuit with two sources connected in series

$$
e(t)=E_{1} \cos (\omega t)+E_{2} \cos (\Omega t)
$$

shown in Fig. 1. We assume that $\omega$ and $\Omega$ are two incommensurable angular frequencies.
The differential equation describing processes in the circuit can be written as

where

$$
\begin{gathered}
\frac{d X(t)}{d t}=A X(t)+B(t) \\
A=\left(\begin{array}{cc}
-\frac{R+R_{L}}{L} & -\frac{1}{L} \\
\frac{1}{C} & 0
\end{array}\right), \quad B(t)=\left(\begin{array}{c}
\frac{e(t)}{L} \\
0
\end{array}\right), \\
\text { is the vector of state variables, } \mathrm{RL} \text { is }
\end{gathered}
$$

$$
X(t)=\left(\begin{array}{l}
i(t) \\
u(t)
\end{array}\right)
$$
a resistance of a choke, $e(t)=e_{1}(t)+e_{2}(t)$.

Let us expand the domain of the differential equation (1) from one independent variable of time t to two independent variables of time $t$ and $\tau$ [4]

$$
\frac{\partial X(t, \tau)}{\partial t}+\frac{\partial X(t, \tau)}{\partial \tau}=A X(t, \tau)+B(t, \tau)
$$




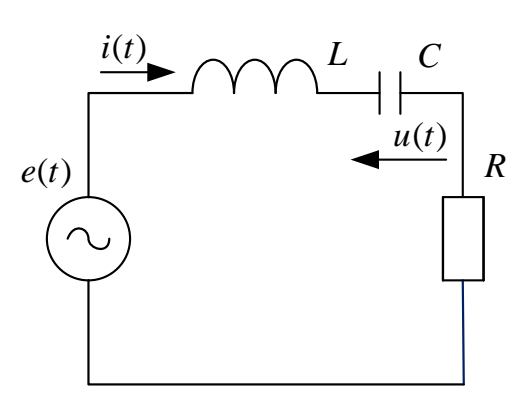

Fig. 1. Analyzed circuit

$$
\begin{aligned}
& \quad X(t, \tau)=\left(\begin{array}{c}
i(t, \tau) \\
u(t, \tau)
\end{array}\right), \quad B(t, \tau)=\left(\begin{array}{c}
\frac{e(t, \tau)}{L} \\
0
\end{array}\right) \text {, } \\
& \text { where } \\
& e(t, \tau)=E_{1} \cos (\omega t)+E_{2} \cos (\Omega \tau) .
\end{aligned}
$$

Applying the two-dimensional Laplace transform [5]

$$
F(s, q)=\int_{0}^{\infty} \int_{0}^{\infty} f(t, \tau) e^{-s t-q \tau} d \tau d t
$$

to (2) and assuming, that initial conditions are equal to zero, i.e. $i(t, 0)=i(0, \tau)=0$ and, $u(t, 0)=u(0, \tau)=0$ one obtains the following equation [3], [6]

$$
\begin{gathered}
(s+q) X(s, q)=A X(s, q)+B(s, q) \\
\text { where } X(s, q)=\left(\begin{array}{c}
I(s, q) \\
U(s, q)
\end{array}\right), I(s, q), U(s, q) \text { and } E(s, q)
\end{gathered}
$$
are images of the vector $X(t, \tau)$, current $i(t, \tau)$, voltage $u(t, \tau)$ and vector $e(t, \tau)$.

$$
\begin{aligned}
& \text { Solving (3) for } X(s, q) \text { we get } \\
& \qquad X(s, q)=[(s+q) I-A]^{-1} B(s, q),
\end{aligned}
$$

where $[\ldots]^{-1}$ is the inverse matrix and $\mathrm{I}$ is the unit matrix.

Let us introduce a transfer function. In contrast with an ordinary definition [4], we define the transfer function as the result of the quotient of images $U_{R}(s, q)$ and $E(s, q)$

$$
\begin{gathered}
T(s, q)=\frac{U_{R}(s, q)}{E(s, q)}= \\
\frac{(s+q) R C}{L C(s+q)^{2}+C\left(R+R_{L}\right)(s+q)+1},
\end{gathered}
$$

where $U_{R}(s, q)=R I(s, q)$ is an image voltage on the resistor $\mathrm{R}$.

Since the image function of sources connected in series in the domain of two variables has the form

$$
E(s, q)=E_{1} \frac{s}{\left(s^{2}+\omega^{2}\right) q}+E_{2} \frac{q}{\left(q^{2}+\Omega^{2}\right) s} \text {, }
$$

then calculating residues at singularity points $s_{1,2}= \pm j \omega$ and $q_{1,2}= \pm j \Omega$ of the image function $U_{R}(s, q)$ one obtains the steady-state voltage

$$
u_{R}(t, \tau)=U_{1} \cos (\omega t-\phi)+U_{2} \cos (\Omega \tau-\psi),
$$

where

$$
\begin{aligned}
& U_{1}=\frac{R C \omega E_{1}}{\sqrt{1-2 L C \omega^{2}+}}, \\
& \phi=\arctan \left(\frac{L C \omega^{2}-1}{\left(R_{L}+R\right) C \omega}\right)
\end{aligned}
$$

and

$$
\begin{aligned}
& U_{2}=\frac{R C \Omega E_{1}}{\sqrt{1-2 L C \Omega^{2}+}}, \\
& \psi=\arctan \left(\frac{L C \Omega^{2}-1}{\left(R_{L}+R\right) C \Omega}\right) .
\end{aligned}
$$

From (6) one can see that this expression is periodic in the domain of two time variables, i.e.

$$
u_{R}(t, \tau)=u_{R}(t+T, \tau+\Theta)
$$

where $T=\frac{2 \pi}{\omega}, \Theta=\frac{2 \pi}{\Omega}$.

The solution in the domain of one time variable can be obtained equating $\tau=t$.

Using the definition of the RMS voltage [7]

$$
U_{R}=\sqrt{\frac{1}{T \Theta} \int_{0}^{T} \int_{0}^{\Theta} u_{R}^{2}(t, \tau) d t d \tau}
$$

one obtains the following expression

$$
U_{R}=\sqrt{\frac{U_{1}^{2}+U_{2}^{2}}{2}} .
$$

It is not too difficult to show that

$$
P=U_{R}^{2} / R \text {. }
$$

In case of the domain of two time variables an active power can be defined as

$$
P=\frac{1}{T \Theta} \int_{0}^{T} \int_{0}^{\Theta} e(t, \tau) i(t, \tau) d t d \tau
$$


Using expressions for $e(t, \tau)$ and $i(t, \tau)$ one obtains the following formula

$$
P=\frac{E_{1} U_{1} \cos \phi+E_{2} U_{2} \cos \psi}{2 R} .
$$

This result also agreed with the calculations of active power for different components of voltage ${ }^{e(t)}$ using the superposition principle.

\section{FREQUENCY RESPONSE}

In order to obtain a frequency response in the domain of two time variables we assume that the input voltage is sinusoidal

$$
e(t, \tau)=E_{p} \cos [\omega t+\Omega \tau]
$$

Applying the two-dimensional Laplace transform one finds the image function

$$
E(s, q)=\frac{E_{p}(s q-\omega \Omega)}{\left(s^{2}+\omega^{2}\right)\left(q^{2}+\Omega^{2}\right)},
$$

and therefore

$$
U_{R}(s, q)=T(s, q) E(s, q) .
$$

The steady-state voltage can be obtained by calculating the residues at singularity points $s_{1,2}= \pm j \omega$ and $q_{1,2}= \pm j \Omega$ of the image function $E(s, q)$. After the calculation of residues one obtains the voltage

$$
u_{R}(t, \tau)=U_{p} \cos \left[\omega t+\Omega \tau-\psi_{p}\right]
$$

where

$$
U_{p}=\frac{R C(\omega+\Omega) E_{1}}{\sqrt{\frac{1-2 L C(\omega+\Omega)^{2}+(\omega+\Omega)^{2} C^{2}}{\left(R L^{2}+2\left(R_{L}+R\right) R+L^{2}(\omega+\Omega)^{2}\right.}}}
$$

and

$$
\psi_{p}=\arctan \left(\frac{L C(\omega+\Omega)^{2}-1}{\left(R_{L}+R\right) C(\omega+\Omega)}\right)
$$

The expressions $U_{p}$ and $\psi_{p}$ depending on angular frequencies $\omega$ and $\Omega$ we call the frequency responses.

Substituting in (5) $s=j \omega$ and $q=j \Omega$ one obtains the frequency response

$$
\begin{aligned}
T(\omega, \Omega)= & \frac{j(\omega+\Omega) R C}{\left[-L C(\omega+\Omega)^{2}+\right.} \\
& \left.j C\left(R+R_{L}\right)(\omega+\Omega)+1\right]
\end{aligned}
$$

From this frequency response the magnitude response can be obtained as follows

$$
T(\omega, \Omega)=|T(j \omega, j \Omega)|
$$

$$
e(t, \tau)=E_{m} \cos [\omega t-\Omega \tau]
$$

the output voltage is expressed by the formula

$$
u_{R}(t, \tau)=U_{m} \cos \left[\omega t-\Omega \tau-\psi_{m}\right]
$$

where the magnitude

$$
U_{m}=\left.U_{p}\right|_{\Omega \rightarrow(-\Omega)}
$$

and phase

$$
\psi_{m}=\left.\psi_{p}\right|_{\Omega \rightarrow(-\Omega)} .
$$

For the input voltage (8) the current through the resistor $R$ is

$$
i(t, \tau)=I_{p} \cos \left[\omega t+\Omega \tau-\psi_{p}\right],
$$

where $I_{p}=\frac{U_{p}}{R}$.

Using expressions (7), (8) and (11) one obtains the active power

$$
P_{p}=\frac{E_{p} I_{p} \cos \psi_{p}}{2} .
$$

For the input voltage (10) the current through the resistor is

$$
i(t, \tau)=I_{m} \cos \left[\omega t-\Omega \tau-\psi_{m}\right]
$$

where $I_{m}=\frac{U_{m}}{R}$.

Using expressions (7), (9) and (11) one obtains the active power

$$
P_{m}=\frac{E_{m} I_{m} \cos \psi_{m}}{2} .
$$

One can see that the form of the expressions for active power $P_{m}$ and $P_{p}$ is the same.

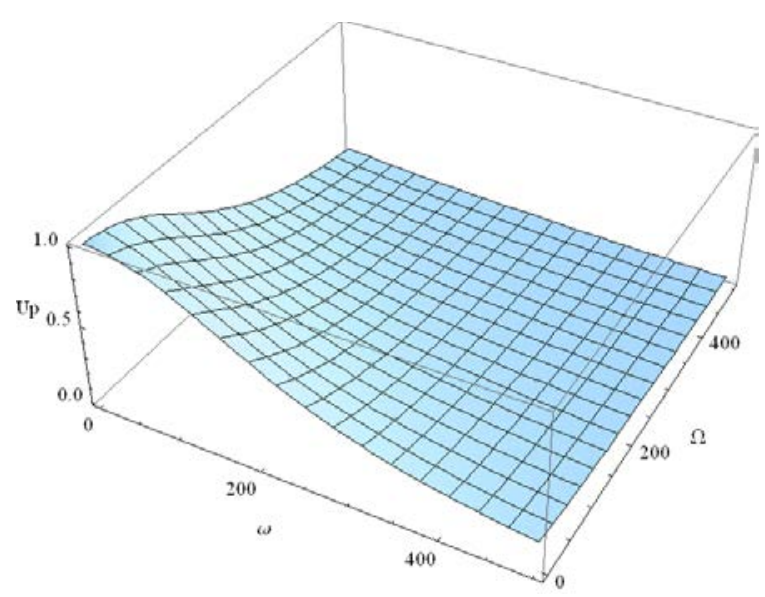

Fig. 2. Magnitude response Up in domain of two variables 


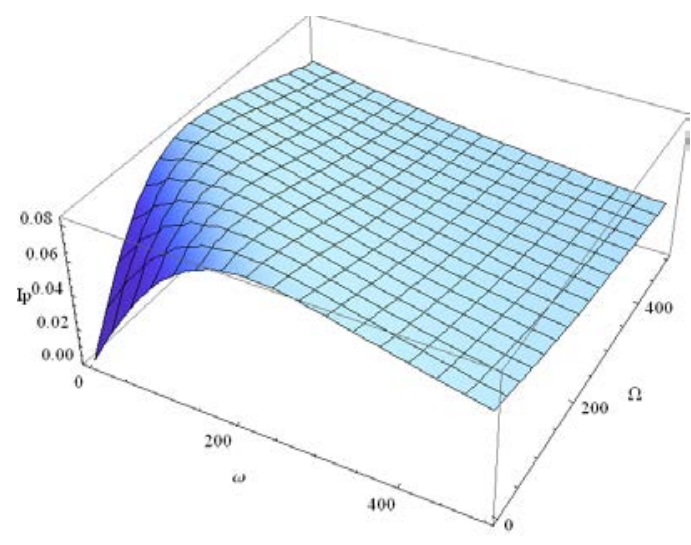

Fig. 3. Magnitude response Ip in domain of two variables

\section{RESULTS OF CALCULATION}

The amplitude-frequency characteristics have been calculated for the circuit with following parameter values: $E_{p}=1 V, \quad E_{m}=1 V, \quad C=0.0007 F, \quad R=12 \Omega$, $R_{L}=0.1 \Omega, L=0.03 H$. The magnitude responses for the input voltage

$$
e(t, \tau)=E_{p} \cos [\omega t+\Omega \tau]
$$

in the domain of two time variables are shown in Fig. 2 and Fig. 3.

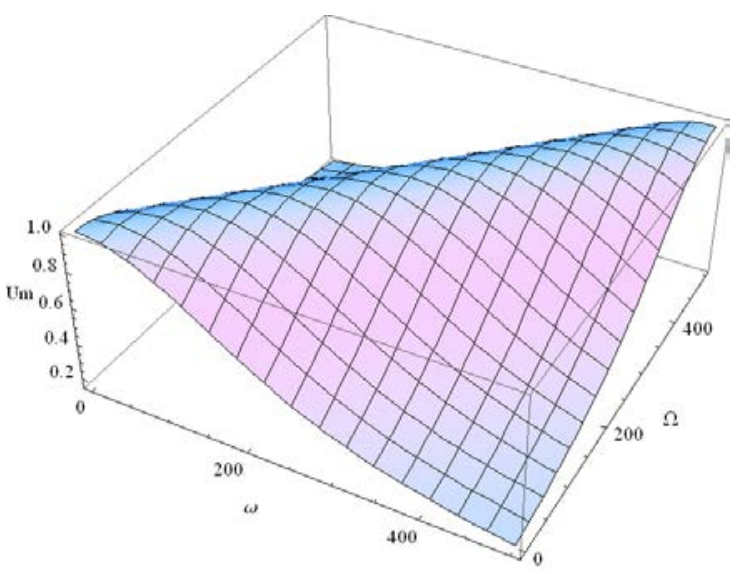

Fig. 4. Magnitude response Um in domain of two variables

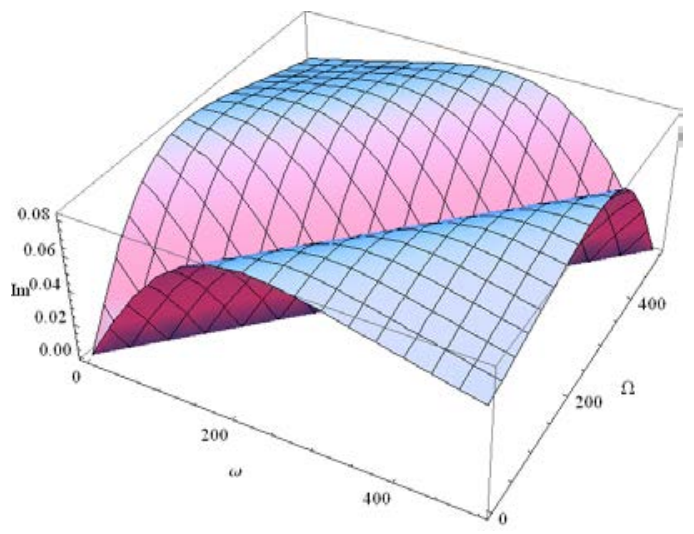

Fig. 5. Magnitude response Im in domain of two variables

The obtained magnitude responses for the input voltage $e(t, \tau)=E_{m} \cos [\omega t-\Omega \tau]$ in the domain of two time variables are shown in Fig. 4 and Fig. 5.

One can see that the magnitude response (Fig. 3) has maximum and then its value decreases with the increasing of frequencies $\omega$ and $\Omega$.

\section{CONCLUSIONS}

In this paper the analyses of processes in the RLC circuit with incommensurable frequencies is considered. The periodic steady-state behavior is defined in the domain of two time variables. The solution of partial differential equations with two time variables is obtained by using the two-dimensional Laplace transform.

The transfer function, active power and frequency responses are defined and the magnitude responses for analysed circuit are presented. These characteristics are the response of the circuit to the sinusoidal signals with sum and difference of angular frequencies.

Double integrals are used for the calculation of the active power in the domain of two time variables. The example of calculation of the frequency characteristics of current and voltage for the RLC load is presented.

\section{REFERENCES}

[1] G. D. Holmes and T. A. Lipo, Pulse width modulation for power converters. Theory and practice. IEEE Press, 2003, ISBN: 978-0471-20814-3.

[2] I. Korotyeyev, "Steady state analysis in PWM inverters based on two dimensional Laplace transform,” Tekhnicheskaia Elektrodin. Silov. Elektron. ta energoefektivnist, no. 4, pp. 182-186, 2012.

[3] I. Korotyeyev, V. Zhuikov, and R. Kasperek, Electrotechnical systems. Calculation and analysis with Mathematica and PSpice. CRC Press, 2010.

[4] K. A. Charles and M. N. O. Sadiku, Fundamentals of Electric Circuits, 5th ed. New York, USA: McGraw-Hill, 2013, ISBN: 978-0078028229.

[5] V. A. Ditkin and A. P. Prudnikov, Operational Calculus in Two Variables and its Application. London, UK: Pergamon Press, 1962.

[6] I. Korotyeyev and M. Klytta, "Process analysis in single-phase half-bridge inverter based on extension of differential equations," Energosbereženie. Energ. Energoaudit, vol. 1, no. 8, pp. 58-63, 2013, URL: https://eee.khpi.edu.ua/article/view/38355.

[7] I. Korotyeyev and M. Klytta, "Analyse of steady-state process in circuits with incommensurable frequencies of voltage sources," in 2016 2nd International Conference on Intelligent Energy and Power Systems (IEPS), 2016, pp. 1-4, DOI: $\underline{\text { 10.1109/IEPS.2016.7521846. }}$.

Надійшла до редакції 14 квітня 2018 р. 
УДК 621.314

\title{
Аналіз процесу в просторі двох змінних
}

\author{
Коротєєв I. Є., д.т.н., проф., ORCID 0000-0002-7990-5413 \\ e-mail i.korotyeyev@iee.uz.zgora.pl \\ Інститут Промислової електроніки www.iee.uz.zgora.pl \\ Зеленогурский университет uz.zgora.pl \\ Зелена Гора, Польща
}

\section{М. Клитта, д.т.н., ORCID 0000-0002-6832-0145 e-mail Marius.Klytta@ei.thm \\ Кафедра Електротехніки та інформаційних технологій Миттельхессенський університет прикладних наук \\ Гіссен, Германия}

Реферат-В статті проводиться аналіз усталених процесів в RLC ланцюзі з джерелами живлення, частоти яких є некратними. У такому ланцюзі не існує періодичного сталого процесу. Для знаходження періодичного усталеного процесу використовуються метод розширення звичайного диференційного рівняння. Це розширення грунтується на введенні нової змінної часу і перетворенні звичайного диференціального рівняння в диференціальне рівняння 3 частинними похідними 3 двома змінними часу. Отримане диференціальне рівняння розв'язусться шляхом вживання двовимірного перетворення Лапласа. Передавальна функція визначається в просторі двох комплексних змінних. Сталий процес в RLC ланцюзі з послідовно включеними синусоїдальними джерелами обчислюється відносно полюсів функцій цих джерел. На основі використання подвійних інтегралів, в просторі двох змінних визначаються вирази для діючого значення напруги на навантаженні та активній потужності. Показано, що виконусться баланс потужностей в просторі двох змінних часу. Потужність, що віддається джерелами живлення дорівнює потужності споживаної навантаженням. Отримані вирази для споживаної потужності також можуть бути знайдені на основі методу суперпозиції. Частотні характеристики визначаються для двох сигналів, що представляють суму і різницю аргументів двох функцій часу. Кожен 3 цих сигналів визначас свою частотну характеристику. Вирази для однієї з частотних характеристик знаходяться зміною знаку частоти сигналу іншої частотної характеристики. Обчислені значення потужностей для кожного з впливаючих сигналів. Отримані вирази для потужностей збігаються 3 виразами обчисленими раніше. Представлені амплітудно-частотні характеристики RLC ланцюга для напруги і струму в просторі двох змінних. Характеристики приведені для двох сигналів, що представлені сумою і різницею двох функцій часу. Амплітудна частотна характеристика, що визначається сигналом з сумою аргументів, має максимум i, потім, із збільшенням частоти зменшусться до нуля.

Бібл. 6, рис. 5.

Ключові слова - простір двох змінних; частотні характеристики; двовимірне перетворення Лапласа.

\section{Анализ процесса в пространстве двух пере- менных}

Коротеев И. Е., д.т.н., проф., ORCID 0000-0002-7990-5413

e-mail i.korotyeyev@iee.uz.zgora.pl

Институт Промышленной электроники www.iee.uz.zgora.pl

Зеленогурский университет uz.zgora.pl

Зелена Гора, Польша

М. Клитта, д.т.н., ORCID 0000-0002-6832-0145 
e-mail Marius.Klytta@ei.thm

Кафедра Электротехники и информационных технологий

Миттельхессенский университет прикладных наук

Гиссен, Германия

Реферат-В статье производится анализ установившихся процессов в RLC цепи с источниками питания, частоты которых являются некратными. В такой цепи не существует периодический установившийся процесс. Для нахождения периодического установившегося процесса используется расширение обыкновенного дифференциального уравнения. Это расширение основывается на введении новой переменной времени и преобразовании обыкновенного дифференциального уравнения в частное дифференциальное уравнение с двумя переменными времени. Полученное дифференциальное уравнение решается путем применения двумерного преобразования Лапласа. На основе использования двойных интегралов, в пространстве двух переменных определяются выражения для передаточной функции, активной мощности и частотных характеристик. Представлены амплитудно-частотные характеристики RLC цепи для напряжения и тока в пространстве двух переменных.

Библ. 6, рис. 5.

Ключевые слова - пространство двух переменных; частотные характеристики; двойное преобразование Лапласа. 